\title{
THE SPIRITUAL SEARCH OF ART OVER ISLAMIC ARCHITECTURE WITH NON-FIGURATIVE REPRESENTATIONS
}

Ar. Sayed Ahmed
Department of Architecture Bangladesh University 15/1 lqbalroad, Mohammadpur Dhaka-1207

e-mail: ar.sayed19@yahoo.com

\begin{abstract}
Art behind Islamic architecture actually based on geometric patterns, developed through a continuous practice over the centuries after centuries by the influences of various earlier cultures such as Greek, Roman, Byzantine, Central Asian and Persian. Basic shapes like squares and rectangles play significant role in Islamic architecture. The reason is, it might recall the principles that govern the order of the world- 'Purity', could only be resembled by pure forms. The façades built by rectangular bricks tend to shape the built form in regular modules. This brickwork casts shadows in strong desert sunlight and creates a three-dimensional effect as light is welcoming message from the Devine source, as it is regarded in all religions. In addition, various pointed starry patterns are common practice and get extremely complex when the outer points are joined together and intersections are connected in a systematic way. Another mode is based on organism of floral forms which recalls the feminine nature of life giving. Again, nobody will argue about the contribution of calligraphy is the most patronized art for decoration. Why have Islamic world choose this universal phenomena? As Allah's creation is pre-decided, the credit of all creativity belongs to the almighty. Also to his messenger, the holy prophet; who taught us to think in this way. The world is only a shadow of real world; here man is on a bewildered search. May be their firm belief; what man can perceive, can only discover the geometric forms to constitute designs which were already existed before in the 'real world'. Discovered geometric forms, therefore, tries to exemplify that perfect reality because creation of Allah has been obscured by the sins of mankind- Art of the complete surrender.
\end{abstract}

Keywords: Islamic art, Islamic architecture,Geometrical patterns, Details in Decoration and Spirituality

\begin{abstract}
Abstrak
Pada dasarnya seni arsitektur Islam menggunakan pola geometris, yang dikembangkan selama berabad-abad dan dipengaruhi oleh berbagai budaya sebelumnya seperti Yunani, Romawi, Bizantium, Asia Tengah dan Persia. Bentuk dasar seperti kotak dan persegi panjang yang sering dipakai dalam arsitektur. Alasan dari menggunakan bentuk dasar seperti itu adalah karena bentuk tersebut merupakan bentukan yang diambil dari prinsip-prinsip tatanan alam. Fasad dibangun dengan susunan batu bata yang cenderung membentuk modul sederhana yaitu dari bentuk dasar persegi panjang. Penggunaan batu bata ini memberikan efek bayangan dari sinar matahari dan menciptakan kesan tiga dimensi yang mendukung suasana religi. Selain itu, berbagai pola bintang dipakai dengan sangat kompleks dimana titik luar dihubungkan dengan cara yang sistematis. Cara yang lainnya adalah dengan menggabungkan unsur-unsur bentuk bunga yang mengingatkan sifat feminin. Seperti diketahui bahwa kaligrafi adalah seni yang diakui kontribusinya dalam memberikan keindahan. Mengapa Islam memilih fenomena universal? Karena ciptaan Allah adalah awal dari semua kreativitas, seperti yang diajarkan Para utusan-Nya, para nabi suci yang mengajarkan kita untuk berpikir dengan cara ini. Dunia ini hanyalah bayangan dari dunia nyata; dan manusia kebingungan mencarinya. Mereka yakin dengan apa yang dilihat dan menemukan bentukbentuk geometris untuk perancangannya. Bentuk-bentuk geometris diyakini sebagai bentukan yang sempurna dalam penciptaan seni, karena penciptaan Allah telah dikaburkan oleh dosa-dosa umat manusia dalam seni.
\end{abstract}

Kata kunci: seni Islam, arsitektur Islam, pola geometris, Detail dalam Dekorasi dan Spiritual

\section{Introduction}

To hold that Islamic art is a perplexing type of art that formed a monolithic appearance of art and architecture is somewhat a dubious proposition. Islamic art is an intuitive art which aims at comprehending the eternal essence, giving evidence that both Beauty and God, exist. To evaluate Islamic art, we should not only consider the vast geographical area with multi-ethnical and cross cultural inhabitants and a long artistic tradition encompassing many designing styles but also it is a cultural acknowledgementdistinguishing certain commonalities to identify the superficial compartmentalization which is unique as Islamic. Accordingly, the key to understand Islamic art over architecture is to recognize the formation of its aesthetics. 
"Islamic art is art which adheres to Muslim aesthetics, regardless of the various geographical and national influences that have bearing on it. What unites different Islamic works of art is their respect for an aesthetic directly tied to the Muslim attitude and conception of the world brought about by the tenets of the religion of Islam"'.

What makes Islamic art Islamic? From the writings of AnandaCoomaraswamy, René Guenon and Titus Burckhardt, we get the conception of traditional art which referred as religious art also for Islamic context. Secularity embedded in the constituent elements of the classical Sunni Islamic tradition by decorative art to express and symbolize the defining ideology of the community. It is never self-expressive or idiosyncratic. This is because of the skill that constitutes the essence of art. In fact, this art makes no distinction between fine arts and crafts. Whether the person is a painter, an architect, a weaver, a poet, a carpenter and a mason, but the fact is, their motto should be making the things well ${ }^{2}$.

\section{Backgrounds}

The art learned by the Arabs, the wandering sons of Islam and the desert, when they came to the land of Eastern conquerors, which were so soon to be conquered- scarcely ever have a people shown such aptitude for adopting foreign civilization and setting a common stamp on art. In Damascus they were pupils of Byzantine art, in Bagdad of Persian; In Northern Africa and Spain they found the teaching of Rome and later Hellenism; and wherever they were pupils they quickly became lords and masters. History of Islamic art has some phases like- the early stages: Pre-dynastic, Umayyad and Abbasid; the Medieval period (9th-15th centuries) with regional varieties: Spain and the Arab Maghreb, Arab Mashriq, Iran and Central Asia, (Ikhanids, The Golden Horde and the Timurids) Syria, Iraq, Anatolia and Mughal India. Again, three Empires had great influence over Islamic art and architecture: Ottomans, Mughals and Safavids.Although the fragmentation deserves sub classifications, there is a coarse division of time. Truth be told, a decent study of chronology is critical to define the three phases in the development of Islamic art. These are follows:

\section{Phase I}

The initial period of its formation, when the first series of Islamic conquests outside the Arabian Peninsula occurred between 634 and 751 has been assumed that Islamic art was formed in each of the conquered region and was relative but varied from one province to another. At beginning, Muslims formulated an attitude of indifference rather than opposition toward representational art. However, it was a historical necessity to preserve its unique qualities, thus consequently rejected representations as an expression of culture and maintained the integrity of its identity; Islamic culture consciously rejected the traditional practices of the territories, it conquered: Byzantines, Persia,
Egypt and Mesopotamia. With no artistic tradition of their own, Muslims of Arabia had a very limited grasp of options, went for visually perceptible symbols and meanings of geometrical forms.

Most elements in early Islamic artistic vocabulary were a continuation of older traditions of Arabia, with a few identifiable exceptions, like Arabic writing, yet to be formed.Religious and civic architecture were developed under the Umayyad dynasty (661-750), when new concepts and new plans were practiced. The Dome of the Rock in Jerusalem is one of the most important buildings in all of Islamic architecture, had a strong Byzantine influence (mosaic against a gold background, and a central plan that recalls that of the Church of the Holy Sepulcher) but bearing purely Islamic elements, such as the great epigraphic frieze.

\section{Phase II}

In the 9th century, Islamic aesthetics were established and achieved popularity widely and grew to dominate other cultures. During this phase, an aesthetic revolution produced the concept for'Muslim art' by its autonomous essence. Many scholars believe that the legalistic aspect of Islamic art became a concern in view of the newly compiled collection of Hadith ${ }^{3}$. However, this Abbasid reign is considered as Golden age, beginning in the mid-8th century, (from 750) lasting until the Mongol conquest of Baghdad in 1258.

Calligraphy, an essential aspect of written Arabic, developed in manuscript illumination and architectural decoration became an important and greatly respected art. This was significant aspect of iconographic and ornamental device. It reached its peak between the 13th and 17th centuries. Besides, the ceramics (especially lusterware), glass, metalwork, textiles, woodwork and Portrait miniature painting in Persia flourished.

To name an architectural example of this period, we can count for the Great Mosque of Kairouan in Tunisia (also known as Uqba Mosque), founded in 670, one of the masterpieces of Islamic architecture. It constituted of a three-tiered square minaret, a large courtyard surrounded by colonnaded porticos and a huge hypostyle prayer hall covered on its axis by two cupolas and was simple by order.

\section{Phase III}

From the end of the 17th century onward, this is the period when Islamic aesthetics stopped governing the art of the Middle East; this art ceased to obey true Islamic aesthetics and allowed an increasing influence and fusion with oriental and occidental arts. This is because of fluidity in Islamic art, (as it is also true for all regional arts) that can travel across time, person and place and can transcend cultural and ethnic boundaries. It created a shared ethos among those who do not have a common religion or race. In Andalusia, for instance, the Mudejar arts were appreciated and cultivated not only by Muslims, but by Jews and Christians alike. In particular, decorative arts; found in 
ornamentation of textiles, ceramics, carpets, tiles, metal ware, fountains, arches and gardens-lend themselves to wider use in a society ${ }^{4}$.

To consider architecture of this phase, we can name theSafavid style, developed in Iran from 1500, when the country was re-united under this dynasty. Unlike their Ottoman neighbors, Safavids had no qualms about depicting human beings in all forms of art. These figures unusually became prominent features of the Safavid style, but floral scrollwork was in parallel practice. When the capital moved to Isfahan about 1600, it underwent a change in styleuntil 1722, as the state fell ${ }^{5}$.

\section{Objective of the study:}

The evaluation of Islamic abstract treatments is based on the analysis of the geometrical patterns with their artistic values. The primary focus of the study is to evaluate the motto of Islamic art and architecture over the philosophy and lifestyle and the sense of articulated spaces by these details. This study has four main objectives, which are illustrated below:

1. To ascertain the abstract representations of effective practice of Islamic architecture, especially showing respect for its traditional values.

2. If possible, to investigate the options to rediscover its message and find out the sprit that how this art absorbed all other cultures on its way.

3. To provide some recommendations over modern practices and treatments of Islamic architecture.

4. To make the people conscious about this thousand years' practice of aesthetics along with Islamic architecture.

\section{Methodology of the study:}

The research is based on two broad approaches:

1. To establish a 'Theoretical Framework' for analysis. (Based on literature review)

2. Deriving results from Empirical basis. (Based on the analysis of the case studies)

The investigation of the particular objective consists of the following steps are outlined below:

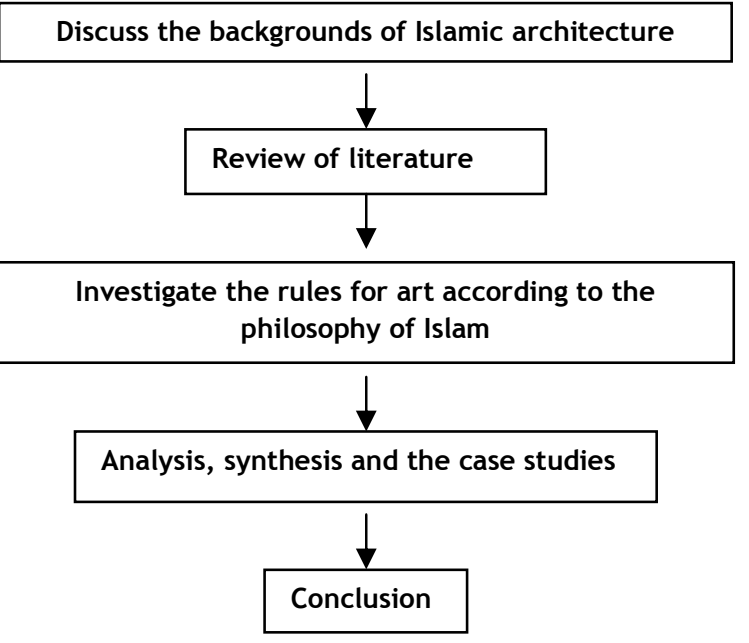

Figure 1: steps of methodology

\section{Content}

Practiced modes for decoration in Islamic art and architecture

There is a great similarity between artworks from very different geographic regions. In fact, the similarities are so pronounced, that it is sometimes difficult for experts to tell where a given piece belongs to. The reason is the rapid communication of new styles within the Islamic world; during the early period and that the science and mathematics are used to construct these designs (especially the geometric art) were universal for their appeal. However, there are threemajor modeswhich created the totality of Islamic decoration (traditionally uses a mixture of calligraphy, geometric and decagonal motif tiling and floral designs) which is going to be discussed in the following sections. These are the reflection of unity arising from diversity which can be identified as a basic tenet of Islam. These patterns, either singly or combined, adorn all types of surfaces, forming intricate and complex arrangements.

\section{Geometric forms and patterns}

The geometric patterns can be equally thought as both art and science because it is at the same time mathematically précised, aesthetically pleasing and symbolic. Due to this duality of creation, the artistic part of this equation can be further subdivided into both secular and religious artwork which is still contextual. Each repeating geometric form has unique built-in symbolism ascribed to itself. For example, the square, with its four equilateral sides, is symbolic of the equally important elements of nature: earth, air, fire and water. Without any one of the four, the physical world, represented by a circle that inscribes the square, would collapse upon it and cease to exist. This principle includes the bare basics of what makes objects structurally sound and, by extension, beautiful.

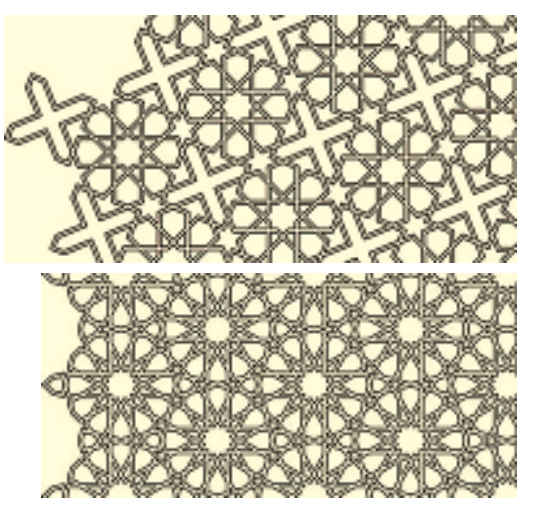

Figure 2: circular and square patterns derived from angles of lines

Surprisingly, the circle is the foundation for Islamic pattern, a consequence of refinements made to the compass by Arabic astronomers and cartographers. It is often an organizing element underlying vegetal designs; plays an important role in calligraphy, also structures all the complex Islamic 
patterns using geometric shapes which the Arabs defined as "the geometry of the line".

Geometric patterns also embody "the idea of negative and positive space and for every negative, there is a positive" seem to inspire a sense of cosmic harmony-whether they are quietly monochromatic or richly polychrome. The relentless rhythms of the Arab world's interlaced starbursts, repeated and infinitum seem perfectly suited to those patterns ${ }^{6}$.

There are an infinite number of ways in which Islamic geometries can be organized to form patterns. These two illustrationsshow yet another pair of patterns, their construction being readily understood, the lower one based on dodecagons and triangles, the top on octagons and squares. This demonstrates how small variations of a simple twodimensional geometry produce very different patterns.

In addition, proliferation of arabesque abstract decoration enhances a quality that could only be attributed to Allah's infinity. "The pattern of the arabesque, without a beginning or an end, portrays this sense of infinity and is the best means to describe in art the doctrine of Tawhid (Divine Unity)"7.

\section{Circular pattern}

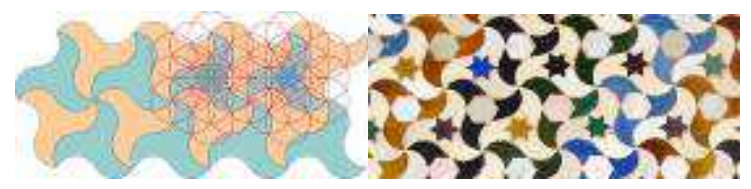

Figure 3: comprising circular patterns from the intersections of circles

There are two illustrations of the same pattern with the $60^{\circ}$ grid laid over the mosaic. This sketch compares the two ways in which the basic pattern can be set out. Above on the right shows the relationship which forms the basis of the pattern on the center of the decorative circular panel above on the left.

In lower illustrations, all circles are same, requiring different centers in 90 grid and intersect each other rather than overlap to occupy a common width as does the pattern on its left. This cursive pattern is known as kite motif.

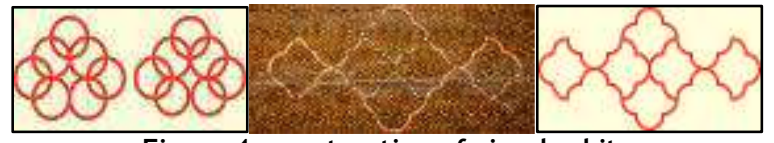

Figure 4: construction of circular kite

Star Patterns

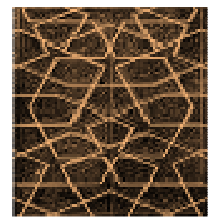

Figure 5: A five point framework
Mixing geometries of different bases is not uncommon in Islamic design. The process adds the possibilities for invention and thus enlivens the designs in which it is deployed. Doing so, the underlying construction can become more complex, particularly in establishing the linking shapes.

Still more complicated stars are seen, including rare examples featuring an astounding 96 points. The given complexity of these starry patterns, some scholars have attempted to link them to mathematics that originated in Arab culture, especially its pioneering exploration of algebra and trigonometry and also the importance of numerology in Arabian culture.

They all have a similar theoretical basis in their constructions but they rely on the skills of designers to understand the underlying geometry of each rosette and to develop the ability of controlling geometry along the reciprocal lines, linking them rationally and artistically. There are many designs similar to it, some simpler, some more complex. Only one is going to be discussed below:

\section{An illustration: five-point pattern construction}

Let us consider a pattern relating the five point geometries to create a complex Saracen pattern. For Muslims, the five points may correspond with the five pillars of faith or their five daily prayers. In order to draw the basic geometrical arrangement, first start with a horizontal line on which raised a vertical through its center. The central pentagon (pink in this picture) is drawn as set out. Next, the sides of the central pentagon are extended until they meet to form a five point star. The five larger pentagons (sky blue colored in the picture), their size yet not established, now each have their two inner sides coincident with these extended lines from central pentagon.

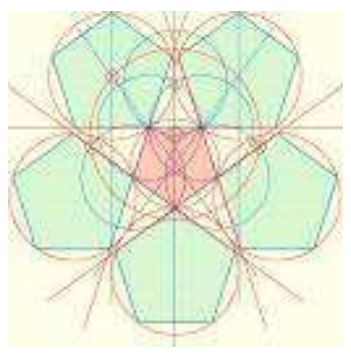

Figure 6:

geometrical features to comprise a five-point pattern

Then two circles each with their center at the two upper corners of the central pentagon and with their radii set at the length of the pentagon's side are drawn. These circles are shown in blue. With its center at their upper point of intersection, another circle of the same radius has to be drawn. The lower point of this circle's intersection with the vertical line had created the center for a circle of larger radius, to be drawn next. This, also, is shown in blue. Now two more circles are drawn, also shown blue in the illustration, with their centers on the 
lower left and right corners of the pentagon and with the same radius; this is the length of the side of the pentagon. These will intersect with the extended sides of the pentagon. The large red circle now drawn with its center at the point noted above and with its radius at the points of intersection of the last two circles with the extended sides of the small central pentagon. Finally, verticals from the centers of the lowest two sides of the pentagon are extended through the upper two corners. These are shown in blue. The points of intersection between these lines and the large circle are the centers of two of the five surrounding large pentagons. The other three pentagons can be constructed by similar methods used to establish the first two. It is dominant that, in this design construction, the central pentagon has been reversed about its horizontal axis.

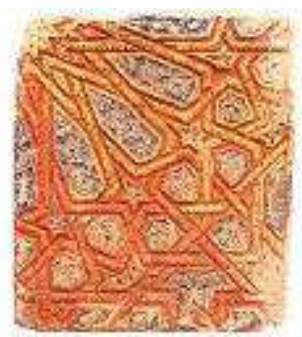

Figure 7:five point star pattern of Nasrid plasterwork in a 16 pointed star Rueda

\section{Pattern selection}
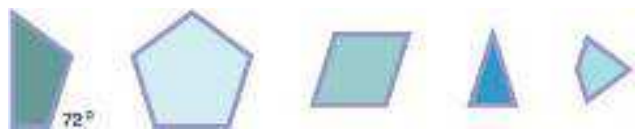

Figure 8: possible shapes to create desirable patterns and angles

The shapes used in the pattern are consist of a half pentagon, pentagon, rhombus, triangle and kite plus. The make-up pieces at the periphery used to complete the rectangular frame. There are some basic shapes that are mirrored and rotated in order to fit to the pattern. the governing angles in the pattern are $0^{\circ}, 36^{\circ}, 72^{\circ}$ and $90^{\circ}$ from the horizontal and these angles are associated with five-point geometry.Pentagons and Octagons appear in Islamic architecture by various shapes in the marble floors. To name, The Citadel of Aleppo in Syria contains marble opus sec tile floors utilizing the square and the eight-pointed star.

\section{Some illustrations of more delicate patterns}

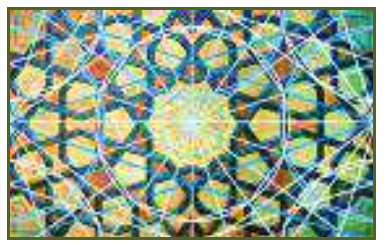

Figure 9: twelve-point geometrical pattern

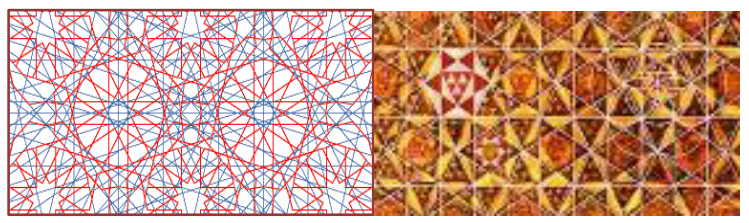

Figure 10: two ten-point geometrical pattern

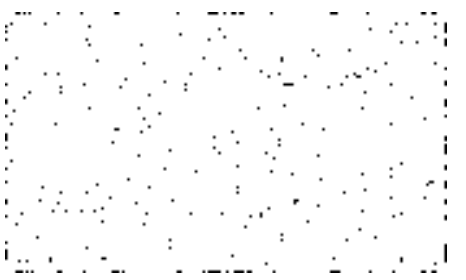

Figure 11: twelve and fifteen point combined geometrical pattern

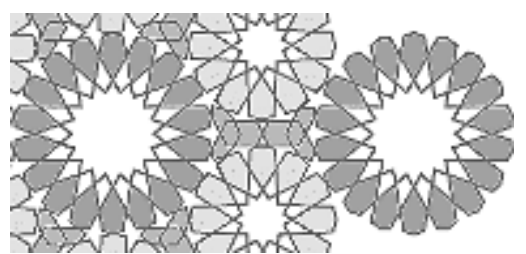

Figure 12: eighteen and twelve point combined geometrical pattern

\section{Vegetal forms}

The second mode is based upon the flowing nature of plant forms and less practiced trend oftraditional Islamic design. Generally this is not the commonest way of decoration in Islamic architecture. The eye is encouraged to move over patterns; finding and re-finding patterns within its infinite two-dimensional geometric base. Though our eyes tend to move over the wall which is decorated with floral motifs in a similar manner, but fail as these are ungoverned by the means of geometric basis. The geometric basis in vegetal form had implied and infinite basis extending in two directions- vertical and horizontal. There is a tendency to read the patterns vertically, horizontal movement of the eye being naturally constrained by the tendrils or stalks. Externally, raised wall decoration reaches considerably higher while a similar treatment to that of the internal walls of any edifice needs a scale factor with appropriate proportion. This practice appears to be completely free-form in its design and there is no geometrical framework behind it. By the means of Islamic decoration; this is, having a contextual relation with Gulf architecture, perhaps having more resonance with Mughal design. The floral designs in the wall are generally raised and engraved, a technique that encourages the sense of touch and enjoyment of the spaces and its containing surfaces.It is evident that the designer has to produce a treatment for this type of decoration to commensurate with the scale of the building. 


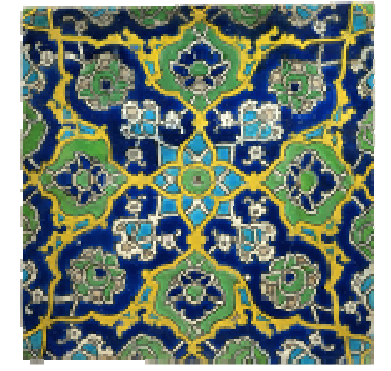

Figure 13: cursive art collected from Iran

\section{Calligraphy}

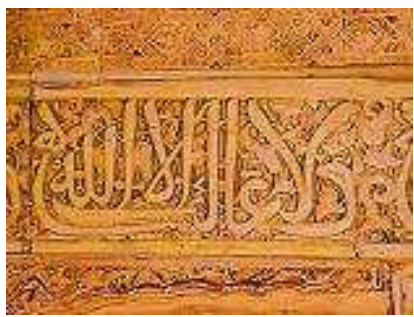

Figure 14: Detail of La SalaMexuar, Alhambra

Instead of recalling something related to the 'True Reality' (the reality of the spiritual world), for the Muslim calligraphy, a visible expression of the highest art of all; the art of the spoken word (transmit of thoughts and of history). In Islam, the most important document to be transmitted orally is, of course,proverbs and complete passages from the holy Qur'an. In Sunni world, Hadith gets notable importance along with Qur'an.

There is a special Chapter (Surah) entitled 'AlQalam' (The Pen) which opens with an Arabic letter nun followed by the Verses:

"Nun! By the Pen and what they write down." [AlQur"an 68:1]

Some scholars like Kamal al-Din HusaynKashifi, R. Guenon etc. are on favor that the letter nun in Arabic resembles an 'ink pot' which contains the ink with which the Divine pen had written the archetypes of all beings or things upon the Guarded Tablet (al-Lawh al-Mahfuz).

Thus, the art of calligraphy reflects on the earthly plane containing the writing of God's words upon the Guarded Tablet, is considered as the origin of the plastic arts in the Islamic architecture. The calligraphy owes its genesis to the Islamic revelation and in reality; it is the response of the soul of the Muslims to the Divine Message. There is an indispensable relation between the Islamic revelation (Sufism) and Islamic art, indeed ${ }^{8}$.

Pointing out the characteristic feature of one of the most primordial Islamic art-forms, calligraphy, Imam Ali ibnAbiTalib says, "The beauty of writing is the tongue of the hand and the elegance of thought." Similarly Abu Hayyan al Tawhidi remarks: "Handwriting is jewelry fashioned by the hand from the pure gold of the intellect".

\section{Geomancy}

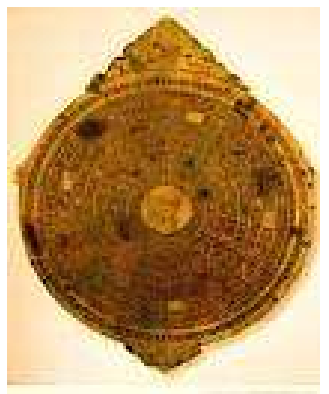

Figure 15: astrological geomancy plate $17 / 18 \mathrm{AD}$, Iran

This is a tradition of divination which has a recurrent practice in the Arabic worlds with a relationship with numbers, not geometry. Distinct from the basic geometries is identified as geomancy. The divination is composed of two elements: numbers and a body of knowledge governing interpretation. Some believe,there is a relationship between geomancy and mathematics and by some extension, astrology and cosmology. This is not only a common trend of Arab world but also pursued in many parts of the world and which is still contextual. The Arabic form was called ' $I \mathrm{~lm}$ al raml' or sand science and related to the making of sixteen random lines on the ground and their interpretation. The conceptual issues underlying these designs are considered to have a hierarchy of geometries relating to the visual form, symbolic meanings and hidden structures or geometries.

\section{Arabesque art}

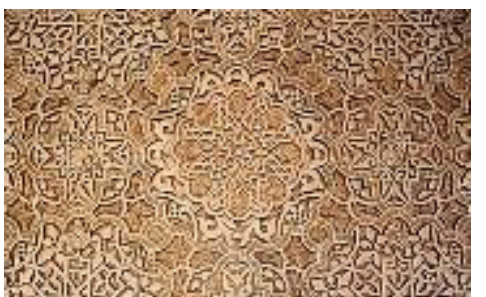

Figure 16: arabesque art with geometric combination

Islamic decorations of architecture are usually distinguished from the Arabesque art. The arabesque is a form of artistic decoration of surface based on rhythmic linear patterns of scrolling and interlacing foliage, tendrils or plain lines, often combined with other elements. To the adherents of Islam, the Arabesque art is a symbolic feature of the united faith and the way, by which the traditional Islamic cultures view the world. Sometimes foliage and linear geometric patterns are combined in a single design and some purely abstract linear patterns are adopted.

\section{Three basic characteristicsof patterns:}

The repeated geometric elements

The simple forms of the circle, square and straight line are the basis of the patterns. These elements are combined, duplicated, interlaced and 
arranged in intricate combinations. Most patterns are typically based on two types of grid-one composed of equilateral triangles, the other of squares. A third type of grid, composed of hexagons, is a variation on the triangular schema. The mathematical term for these grids is "regular tessellation" (deriving from Latin tesserae, i.e., pieces of mosaic), in which one regular polygon is repeated to tile the plane.

\section{The two-dimensional designs of background and} foreground pattern

The placement of pattern upon a pattern serves to flatten the space, and there is no attempt to create depth. Vegetal patterns are may be set against a contrasting background in which the plantlike forms interlace, weaving over and under in a way that emphasizes the foreground decoration. In other instances, the background is replaced by a contrast between light and shade. Sometimes it is impossible to distinguish between foreground and background. Some geometric designs are created by fitting all the polygonal shapes together like the pieces of a puzzle, leaving no gaps and therefore, requiring no spatial interplay between foreground and background. The mathematical term for this type of construction is only "tessellation".

\section{Design beyond framing}

Geometric ornamentation in Islamic art suggests a remarkable degree of freedom. The complex arrangements and combinations of elements are infinitely expandable; the frame surrounding a pattern appears to be arbitrary and the basic arrangement sometimes provides a unit from which the rest of the design can be both predicted and projected.

\section{Modern concept: quasi-crystalline geometry}

Surface patterns on architecture have been prized for their beauty, refinement, harmony, intricacy, and complexity. In geometry, Medieval Islamic art from the 15th century intuitively echoed principles of quasi crystalline geometry which were discovered 500 years later. But Harvard's Peter Lu and Steinhart now argue that the patterns were created by tessellating a small number of different tiles with complex shapes, evolving into what would now be described as quasi-periodic shapes.According to Lu and Steinhart, Quasi-crystal is a structure that is ordered but not in a periodic way where use of both symmetrical and polygonal shapes created the patterns that can be extended indefinitely without repetition. Hitherto, the conventional view of Islamic design was that the complicated star and polygon patterns were conceived as zigzagging lines, drafted by using straight edge rulers and compasses. A quasi-crystalline pattern can continuously fill all available space, but it lacks translational symmetry. This indicates intuitive understanding of complex mathematical formulae, even if the artisans had not worked out anyunderlying theory.

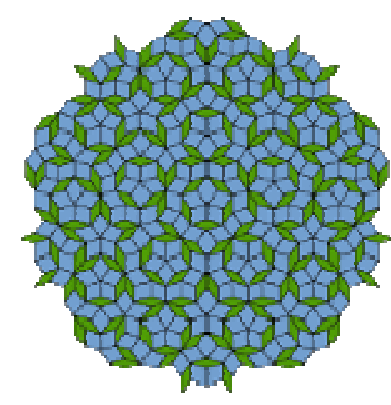

Figure 17: Penrose pattern in quasi-crystalline

Some practices and techniques in Islamic architecture

Girih

Girih (Persian: "knot") is an Islamic decorative art form consisting of geometric lines of an interlaced strap work that form six, eight, ten or twelve-pointed stars separated by polygons and straps. Such patterns usually consist of a repeating "unit cell" with two, three, or six fold rotational (Straight-edged) symmetry that tiles the plane with no gaps.Girih has been defined as "geometric (often star-and-polygon) designs composed upon or generated from arrays of points from which construction lines radiate and at which they intersect." In Iranian architecture, GerehSazipatterns were used in Banna'i brickwork, stucco, and mosaic faience work. The three-dimensional equivalent of Girih is called Muqarnas, to decorate undersides of domes or Squinches. The picture illustrates Girih patterns on walls flanking the portal of the HunatHatun Madrasah (Seljuk architecture, 11781243) in Kayseri, Turkey.

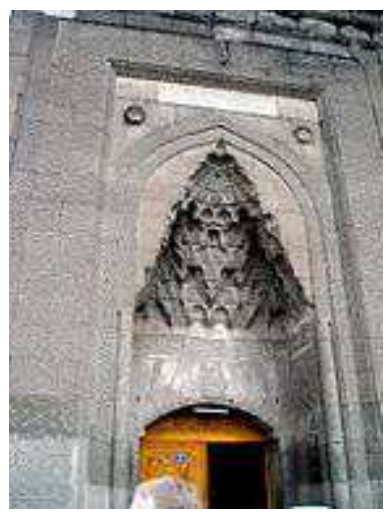

Figure 18: Muqarna in HunatHatun Madrasah, Turkey

For instance, The Topkapi Scroll from the late 15th century, documents that the girih lines superimposed with the tiles used to generate the Girih pattern. Blue line shows the Girih pattern, thin and red lines indicate outline of Girih tiles. 


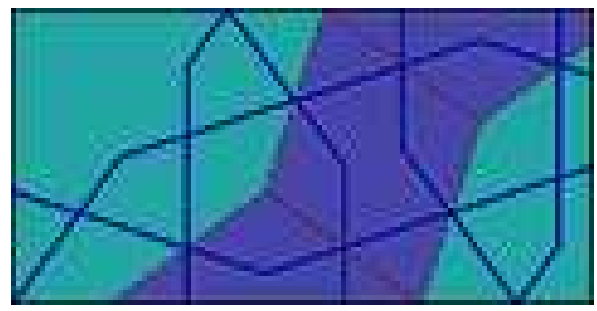

Figure 19: Girih pattern

Naqsh

It can be treated as a combination of calligraphy and floral art. Generally it is carved plasterwork around any fenestration. This example of Naqsharound a doorway in Isfahan indicates both comprising calligraphic and foliate elements in their integrated designs. This is known as foliate Kufic.Two types of written calligraphy were preferred, Kufic and cursive. Kufic, was patronized directly by Hazrat Ali, which originated from the town of Kufa in Iraqand is geometric and has distinct rigidness. Due to this physical characteristic, Kufic is ideal for wall inscriptions of islamic architecture. The cursive script, the more popular of the two is precisely what the term implies, flowing and easily readable. Basically, all other Islamic scripts are variations of the Kufic and cursive. All of them tend to be highly inventive and frequently seem like a new style. In architecture and in the writtings of Quran, Muslims invariably used a combination of both the Kufic and the cursive scripts. ${ }^{9}$ In Shiraz, Iran; they developed Thuluth calligraphy, more freestyle form andexecuted on glazed tile work. Again, there appears to be no geometric framework behind the designs. However, the ascenders create the appearance of a grid while the cursive letters act as counter foils to them, reinforced in detail by small, fairly representative, plants including leaves and flowers, introduced as two colors, yellow and red to contrast with the white calligraphy on the dark blue ground.

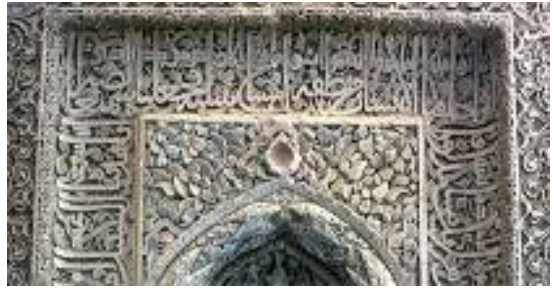

Figure 20: Kufic Naqsh around a doorway in Isfahan, Iran

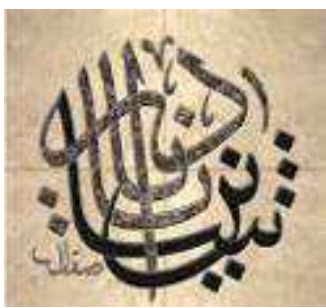

Figure 21: JaliThuluth of Iran executed in marble and granite

\section{Mosaics}

Some of the best examples of Islamic mosaics were produced in Moorish Spain. For example, the golden mosaics in the Mihrab and the central dome of the Great Mosque in Cordoba. They were made between 965 and 970 during the reign Umayyad Caliph of Spain, by local craftsmen, supervised by master mosaic specialists from Constantinople and had decidedly Byzantine character. The decoration is composed of colorful floral arabesques and wide bands of calligraphy. Historians say, the mosaics were purported to evoke the glamour of the Great Mosque in Damascus.

Mosaics generally went out of fashion in the Islamic world after the 8th century. Similar effects were achieved by the use of painted tile work, either geometric with small tiles, sometimes called mosaic, like the Zillij of North Africa, or larger tiles painted with parts of a large decorative scheme (Qashani) in Persia, Turkey and further east.

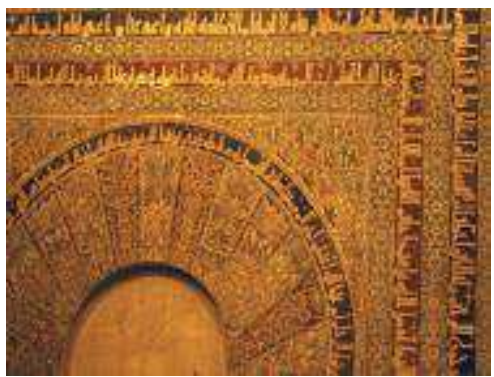

Figure 22: mosaic tiles in Minbar of Alhambra

\section{Case study}

At first, some case studies from different parts of the world considering different architectural features including different periods of styles:

Islamic architects and artists appropriated key elements from these classical traditions, and then elaborated upon them to invent a new form of decoration that stressed the importance of unity, logic, and order. The contributions made by Islamic mathematicians, astronomers, and other scientists, whose ideas and technical advances are reflected in the artistic tradition of Islam implicitly ${ }^{10}$.

Studying the features of Islamic architecture, specialists find no specific religious or spiritual reason for the domes as well as we do find the philosophy behind Stupa for Buddhist architecture or 'nine grid Mandala' for Hindu temple. It's purely architectural and was implemented successfully by the Muslims which they obtained from the Byzantine, Persian and Syrian-Arab designs. Besides, The Persian world is summit of buildings with decorative brickwork, especially during the Seljuk period.In traditional ornamentation, the new 'Haft Rangi' (seven-colour) style of tile mosaic (a full palette includes dark Persian blue, light Turkish blue, white, black, yellow, yellowy-green shades, green and biscuit) brought renaissance in Persian dome construction initiated by the Safavids. According to Jean Chardin, it was the low humidity in the air in Persia that made the colors more vivid and the 
contrasts between the different patterns is too stronger in the Haft Rangi method. The facades are covered with beige marble up to two meters from the ground and religious texts written in white Thuluth script on a dark blue ground frames. Reflecting the light of the sun, these domes appeared like glittering turquoise gems and could be seen from miles away by travelers following the Silk Road through Persia. These distinct shaped, bluecolored domes dominated the skyline of the city of Isfahan.
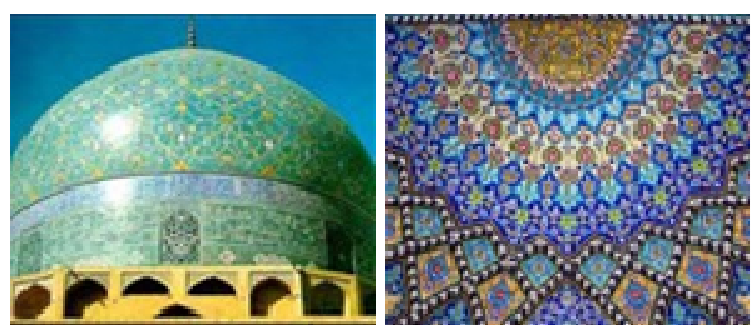

Figure 23: Imam Mosque, Isfahan, Iran, completed in 1629 by ShaykhBahai, Four-Iwan style with 'Haft Rangi'

The Great Mosque of Cordoba is another example further west in Spain. Though Alhambra palace in Granada, Spain is a famous example of repeating motifs in tile work and stucco decoration, The Great Mosque at Cordoba marks the beginning of Islamic architecture in Spain and Northern Africa. Moorish architecture reached its peak with the construction of its interior spaces adorned with stylized foliage motifs, covered in glazed tiles, Arabic inscriptions and arabesque designs. The building is most notable for its arcaded hypostyle hall where striking interior arches resting on 856 columns of jasper, onyx, marble, and granite. These double arches were a new introduction to Islamic architecture, permitting higher ceilings than would otherwise be possible with relatively low columns and consist of a lower horseshoe arch and an upper semi-circular arch. The famous alternating red and white Voussoirs of the arches were inspired by those in the Dome of the Rock.

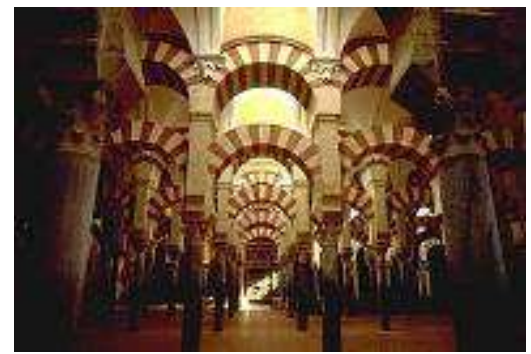

Figure 24: Great Mosque of Cordoba, Spain, dating from 785

If two of above illustrations are considered as decorative invention, the next one might be described as a respect! This is example of vernacular
Islamic architecture where mud cladding \& wood construction were implemented with minimum decorations as mud doesn't provide enough opportunity of sustainable art work over the facades. It is said that the Mosque's courtyard built to the exact dimensions of the Ka'abah in Mecca, using a rope for precise measurements.

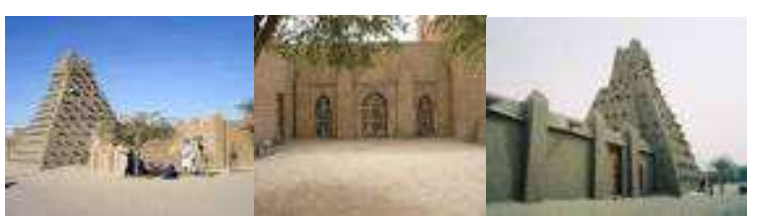

Figure 25: Sankoré Madrasah and Mosque at Timbuktu, Mali, 1324-1327 AD, by Mansa Kankou Musa.

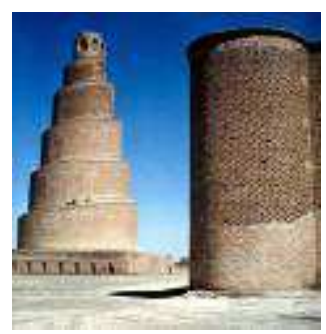

Figure 26: The Minaret of Samarra, (Malwiya Minaret) of Great Mosque of Samarra, Iraq, during 848 - 852, by the Abbasid caliph Al-Mutawakkil, constructed by sandstone, destroyed in 1278 AD by Hulagu Khan.

Again, negotiation of local tradition was not omitted on the way of Islamic architecture. Next two examples are presented as an evidence of this statement. It is unique among other minarets because the minaret was originally connected to the mosque by a bridge. Unlike most minarets, the Malwiya was not used for the "call to prayer"; its height made it impractical for such use. However, it is visible from a considerable distance in the area around Samarra and therefore may have been designed as a strong visual monument of the presence of Islam in the Tigris Valley.

The word "Malwiya" translates as "twisted" or "snail shell". It is a vast spiraling cone of 52 meters high and 33 meters wide at the base, the spiral ramp contains stairs reaching to the top. At the top of the cone is a small cylindrical room with a six-meter radius. This room is decorated with eight arcs on the outside; each arc is erected on two small brick posts. Stucco carvings in floral and geometric designs represent early Islamic decoration and were influential.

For another instance in this regard, can be the Menara Kudus Mosque's tower; was built in a Javanese Hindu brick temple style. This is similar to the Drum towers, an integral component of Hindu Balinese temples called kul-kul, was a place for Bedug, a huge drum which is beaten to the summons of prayer in Indonesia.

This might be illustrated as the fusion of Islamic architecture where Hindu-Buddhist architectural elements are preserved and suggest a continuation of an earlier tradition into the Islamic 
era in Indonesia as Minarets were not originally an integral part in Indonesian mosque. Probably this tower had a Meru roof supported by large pillars, as in Cirebon and Demak features and wooden tiles, with glass windows inserted between the roof tiers $^{12}$. The roof is topped with a Mastaka crown roof element. From broad sense, there are three distinct identities that reflected in the architecture of mosques in different part of the Indonesian Archipelago: Sumatran, Javanese and eastern Indonesian territories (Borneo, Celebes, and Maluku). On contrary, the complex includes a Mogulstyle mosque with a silvery onion-dome and concrete pillars, a latter addition indeed.

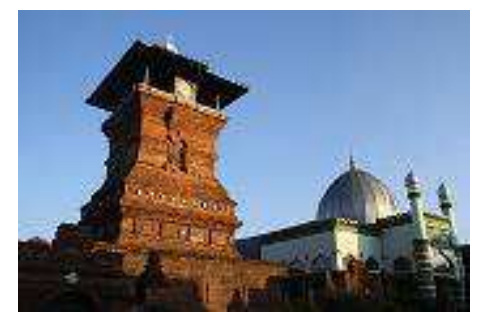

Figure 27: The Menara Kudus Mosque's tower, Central Java, 16th century, Hindu-Buddhist style of the Majapahit era, by Ja'farShodiq in 1549

Secondly, the art associated with interiors, finish materials, decorative features and ornamental details:

Nur al-Din room, dated 1707 A.D. Ottoman period, Syria, attributed to Damascus

Wood, marble, stucco, glass, mother-of-pearl, ceramics, tile, stone, iron, colors, and gold; $22 \mathrm{ft}$. $1 / 2$ in. $x 16$ ft. $81 / 2$ in. $x 26$ ft. $43 / 4$ in. $(6.7 \times 5 \times 8$ m)

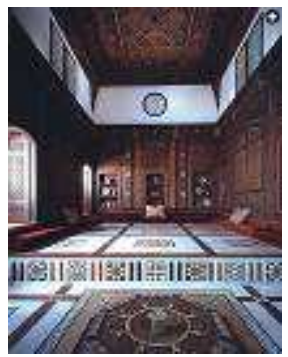

Figure 28: the upper class room of Syria moved to NY metropolitan art museum

This room was the winter reception room in the home of a wealthy Syrian man. Male guests would enter the room, leave their shoes at the step, and ascend to the reception area, where host and guests would relax on pillows placed on long benches that lined the wall. In the area in front of the steps, servants would prepare food, coffee, and a water pipe for the guests. The room also has niches for books, water pipes, and a collection of ceramics and metalwork. Closets were used to store mats and bedding. The floor is made of marble tiles and the wooden walls and the ceiling are ornamented with gesso. Every surface is richly decorated with multiple patter ns and abundant use of gold. The decorations are mostly vegetal and calligraphic.

Openwork or piercing screen (Jali) 1610; Mughal period, India, from Agra

Marble; $481 / 8 \times 161 / 2$ in. $(122.2 \times 41.9 \mathrm{~cm})$

Pierced screens (Jali in India) are common geometric decoration. These screens of pink sandstone or white marble were widely used in Mughal India and fulfilled many architectural functions, serving as windows, room dividers, and railings. They allowed for the circulation of air and provided shelter from sunlight, but the geometric patterns and their projected shadows also produced aesthetic effects ${ }^{11}$.

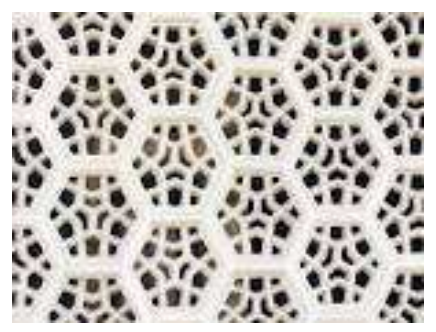

Figure 29: Jali of Agra, India

An Islamic artifact:woodenMinbar, Egypt, $15^{\text {th }}$ century

This is a fifteenth century wooden Egyptian Minbar that has been articulated with Pendentives, a form of cantilever that is commonly used in masonry constructions. This is more decorative than structural due to the inherent character of timber which has both compressive and tensile qualities while stone has only compressive one. Egyptian artists created very intricate designs like this one in many materials.

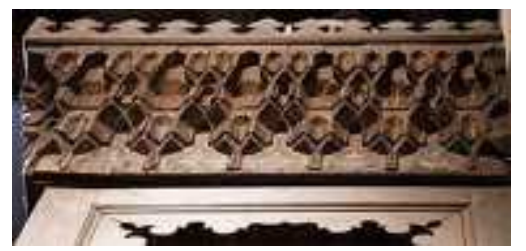

Figure 30: wooden Minbar with curved muqarnas

Cupola dome, Suleiman Mosque, dated1575, Ottoman period, Istanbul, Turkey

For almost 500 years, Byzantine architecture such as the church of Hajia Sophia served as models for many of the Ottoman mosques such as the Shehzade Mosque, the Suleiman Mosque and the Rüstem Pasha Mosque.Turkish (Ottoman Empire) architects implemented their own style of cupola dome which forms a distinctive characteristic in Islamic art. 


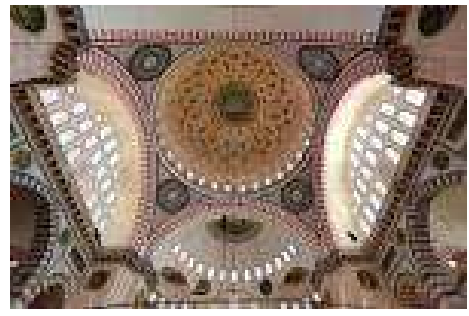

Figure 31: Suleiman Mosque, Istanbul

They mastered the technique of building vast inner spaces confined by seemingly weightless yet massive domes by achieving perfect harmony between inner and outer spaces. Islamic religious architecture was transformed by the Ottomans through a dynamic architectural vocabulary of vaults, domes, semi domes and columns which was simple in earlier. The mosque was transformed into a sanctuary of esthetic and technical balance, a hint of heavenly transcendence rather than a cramped and dark chamber with arabesque-covered walls. The art over dome echoes the earlier practice and not different from those, which are Islamic.

\section{Spirituality:Rules of Representation}

"What is the meaning of "spirituality" and its relation to "religion"? The disposition of the heart and will, through which a man comes to care for the highest things and to live in gentleness and inward calm above the surface aspects and accidents of life, we call, in its inner nature, spirituality; when it is embodied in outward forms and institutions, and spread among whole communities, we call it a religion" ${ }^{13}$.

And culture is somewhat we do in any particular community; this 'doing' definitely involves building a piece of architecture, decorate its facades or interiors with inherent, intuitive and instinct skills, that we call art.

\section{Philosophy oflslamic Art}

The Qur'an provides the set of guidelines of Unity while the Prophet provides the manifestation of this Unity into multiplicity and the witness to this Unity in Allah's creation. In brief; Islamic art is the result of the manifestation of Unity upon the plane of multiplicity. Al-Tawhid (Unity of Being) is the real meaning of Islam and this metaphysical belief of Unity has the spiritual significance of the Void (universe) which is the only aspiration and soul of Islamic art ${ }^{14}$. In fact, the Qur'an neither specifically prohibits the making of idols, nor contains anything as strong as the condemnation of imagery found in the various texts of the Hebrew Bible. For Muslims, God is understood only as an abstract force. Therefore, it is not only sacrilegious but also truly illogical to portray him in a form borrowed from his own creation.

For this interdiction, Muslim artists made sure that their work did not appear "real" and adopted the practice of two-dimensional pictorial space with forms and colors assembled in a certain order. All tangible appearances of nature had to be abandoned, including perspective, chiaroscuro and modeling according to the Aristotelian aesthetics, 'the most perfect possible imitation of nature' adopted by all Semitic theologies. Instead of the linear perspective used later in the West to organize space, Muslim artists utilized a spiritual perspective. This perspective follows spiritual rules governed by the understanding of the relationship between God's eternal existence and the transient existence of the world at large. Accordingly, Muslim artists can show the inside and outside of a building at once, and do not need to conform to any natural laws in their use of light and shadow.

Islamic art mirrors the timeless ideals of Islam expressed within a particular place and time. It manifests both perennial and spiritual values as well as local notions of aesthetics and craftsmanship. Islamic art plays on the concept of the One and the many: the One as the bounteous source of the many and the felicitous return of the many to the One. The art directs attention to God's nearness, yet mystery, through aesthetic experiences mediated through the senses, experiences that evoke the wonder of creation. It is often said that art in Islamic cultures exists not just for the sake of art itself, but to act as a constant reminder of the beauty of God's presence. Both nature (God's creation) and the arts (human creations) are understood as intimations of Divine mercy ${ }^{15}$.

For Muslims, the best art that can be created by man is the art that displays the underlying order and unity of nature as well as this material world. However, there is no distinction; all forms of art, mathematics and science; all are creations of Allah and therefore reflect the same thing - that is, Allah's will expressed through his creation. This belief, accordingly; the natural world is a mere ghostly approximation of that spiritual world, where the only true reality exists.

\section{Philosophy of Islamic Architecture}

The roles of the Qur'an and the Prophet's Sunnah to shape the identity of Islamic architecture summarized in the following concepts: education, guidance, inspiration, thrust, point of reference and contentment. It follows that any Islamic architecture must address firstly the subject of the Qur'an and Hadith (Sunnah) as its conceptual base and then followed by mastering the building technology and engineering of the era and by duly answering the requirements of the general circumstances of a given age and a geographic zone ${ }^{16}$. In fact, Islamic architecture is a fine blend of all the factors like aspects in process and proper understanding which are interwoven with the treads of the belief, principles and teachings of prophet and ethical values of Islam ${ }^{17}$. Moreover, Prophet Muhammad (PBUH) viewed architecture as neither a sheer religious ceremony nor a completely and solely secular business. The only one thing that he prohibited was the practice of erecting luxurious and exaggerated buildings; even it is true for mosques.Central idea about Islamic architecture is 
function with all of its dimensions: corporeal, cerebral and spiritual. The form, divorced from function, is inconsequential. This, however, by no means implies that the form plays no role in Islamic architecture rater it plays a prominent role, but its relevance is supportive one, for supplementing and enhancing the function.In terms of value and substance, form always comes second to function with its wide scope. Likewise, light reveals the casting shadows of brickwork. To count the overall practices, there are eight main traditions in Islamic of architecture: four major and four minor. The major ones include the Arab, the Iranian, the Turkish and the Mughal (Bangladesh, India and Pakistan)and the minor ones are, the West African, the East African, the Indonesian and the Chinese ${ }^{18}$.

Here are the uses of natural elements with along with architecture, sun light for both interior and exterior, while water and tree for landscape.

\section{Light}

According to one hadith (tradition): "A person of faith in a mosque is like the sun reflecting in the water."19 In Islamic architecture, light functions decoratively by modifying other elements or by originating patterns. Proper light reveals the pierced facades which look like lacy, disembodied screens. Light adds a dynamic quality to architecture, extending patterns, forms and designs into the dimensions of time. The combination of light and shade creates strong contrasts of planes and gives texture to sculpted stone, as well as stocked or brick surfaces.

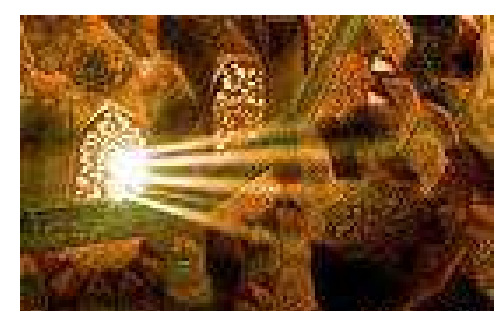

Figure 32: screen from Alhambra, Spain

\section{Water}

In hot Islamic climates, the water from courtyard pools and fountains cool as it decorates. Water cannot only reflect architecture and multiply the decorative themes; it can also serve as a means of emphasizing the visual axes. Like the images they mirror, pools of water are immutable, yet constantly changing; fluid and dynamic, yet static ${ }^{20}$.

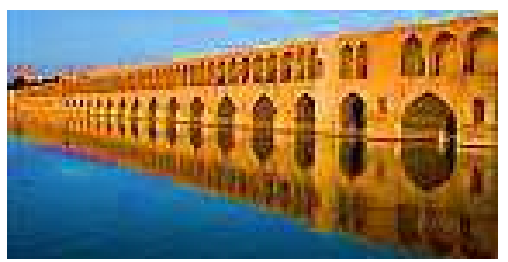

Figure 33: Si-yo-se-pol, Isfahan, Iran
Tree

Palms set the stamp of the desert on all these gardens, since for the Arabs; palms were the venerated trees of their true home and gave them, all in one: cool shade, repose and the beauties of the natural world. Thus Arabs took the palm wherever they went, and did a great deal towards naturalizing it in the rest of the world.

They were fond of sweet-smelling plants and all manner of roses, also oddly-grafted trees. The Arabs liked artificial culture: different fruits on one tree, different grapes on one vine;they thought this assorted combinationis pleasing. They liked to have flowers of unnatural colors and to graft a rose upon an almond-tree.

For instance, prince Muktadir, build the House of the Tree which took its name from a tree made of gold and silver, standing in the center of a great round pond. This tree had eighteen boughs of gold and silver, and innumerable branches covered with all sorts of fruits that were consist of precious stones. On the branches sat birds' which were made of gold and silver, and when a breeze passed through, they whistled and sighed in a wonderful way.

From another source, geographer Jakubi, in his writing about Samaria in the year 889 , said that the founder of Samaria garden was Muhtasim (a son of caliphate Harun-Ur-Rashid), whose first care was to conduct water from the Tigris by canals so that everything can prosper on the virgin soil. He entrusted the cultivation of trees such as date palms, also vines and many other hedges, were imported from Basra and Bagdad. These palms bore large dates, and ripe fruit was always there, in the beds were melons and other fruits ${ }^{21}$.

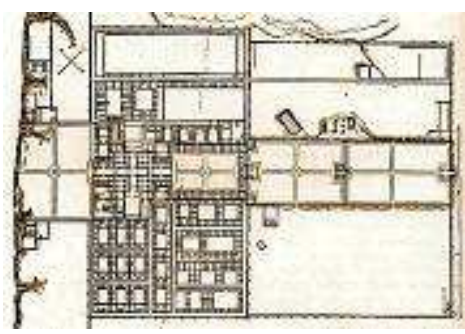

Figure 34: plan of Balkuwara palace, Samaria

\section{Conclusion}

Islamic art over architecture, offers a 'vista' into Islamic culture and a variety of perspectives on enduring themes that have propelled human history and fueled the rise of world civilization over the centuries. Islam might have invented in Arabia, but it gained scholastic aspects in Egypt, revived in Iraq, got the governing legislation in Turkey, captured the artiste in Spain, absorbed philosophy from Iran and triumphed through Indian subcontinent and Malay tropics. This travel of art, on the facades of architecture is a socio-cultural fusion and reflects the multicultural continuity of contributions where surprisingly the 'core' perception remained the same. Thus this study takes an arbitrary journey 
across nine countries, reveals the commonalities in a shared artistic heritage from the edges of Islamic worldand ranges 1,400 years of history.It explores the richness ofvarious features, from great ornamented domesto the exquisite beauty of carved inscriptions on door fringes. Even, the playfulness of light in monumental mosques and insulation of water turned into an expressive, useful art form.

But what is the gravity from Islamic art's (architecture also) soul? This paper proclaims, the unique way by which Islamic art turns calligraphy and the written word into masterpieces. The why is, Islam shared a language; Arabic (and partially Persian, but the same alphabets)which they not only used for their theological, philosophical, legal and scientific writings but also for decorative purposes;from miniature art to massive architecture. Moreover, this multi-dimensional exchange of ideas, textsand forms of decoration is the only norm rather than the exceptions. The art of calligraphy revel the unity and at the same time, paves the way for diversity.Likewise, it incorporates the basic themes of transcendent beauty, universal to all creative endeavors in Islamic world. Eventually, the success of this paper can be evaluated that the question rose by it and need further research, indeed.

\section{References}

1. Nada Shabout, "Modern Arab Art: Formation of Arab Aesthetics," University of Florida Press, June 2003.

2. Edward Madden, some characteristics of Islamic art, University of Buffalo press, 1972 page 1.

3. Papadopoulo, Alexandre, Islam and Muslim Art, trans. by Robert Erich Wolf. New York: Harry N. Abrams, Inc., 1979.

4. Ethics and Aesthetics in Islamic Arts by Dr. Tazim R. Kassam on September 3, 2011 in Art, Philosophy. Chief Editor, biannual 'Spotlight on Teaching', American Academy of Religions.

5. Style in Islamic Art - 1500-1700 A.D in Ottoman, Safavid style, Islamic-arts.org Team, March 15, 2011.

6. AchvaBenzinberg Stein, Morocco: Courtyards and Gardens, Monacelli Press, 2007.

7. Wijdan Ali, the Arab Contribution to Islamic Art, American University in Cairo Press, 1999.

8. Nasr, SeyyedHossein. Islamic Art and Spirituality, New York: State University of New York Press, 1987, op. cit., p.18.
9. Understanding Islamic Art of the 16th \& 17th Centuries, The Art History Archive - Arabic Art, the Collection of Prince Sadruddin Aga Khan, By Shehbaz H. Safrani.

10. Articles of Nada Shabout, University of Florida press, June 2003.

11. The Aesthete: Exploring Geometric Patterns in Islamic Art, by Mitchell Owens on architectural digest, April 12, 2012.

12. Miksic, John in Java - Periplus Adventure Guide, 1997. pp. 246-247.

13. Durant Drake, Problems of Religion, (Houghton Miffline Company), p.244.

14. Nasr, S. Hossein, Islamic Art and Spirituality, Golgon Press, Ipriwich, Suffolk, 1987, p. 185.

15. Nada Shabout, "Modern Arab Art: Formation of Arab Aesthetics," published by the University of Florida Press, 2007.

16. Lessons from Prophet Muhammad (saw) mosque, Spahic Omer, intellectual discourse, volume 18, no 1, 2010.

17. Islamic Architecture: Its Philosophy, Spiritual Significance, and Some Early Developments, Spahic Omer, 2009.

18. Islamic Art and Its Spiritual Message Dr. Khawaja MuhammadSaeed, Dept of philosophy, University of the Punjab, International Journal of Humanities and Social Science Vol. 1 No. 2; February 2011.

19. SeyyedHosseinNasr"s/slamic Art and Spirituality, op. cit., p. 37

20. Dalu Jones, "Surface, Pattern and Light" in Architecture of the Islamic World, chapter: Its History and Social Meaning, p. 144-175. 1978, Thames and Hudson, London.

21. A History of Garden Art, Islamic garden design by Marie-LuiseGothein, 1928, 2nd volume, London. 